\title{
PENGARUH MOTIVASI KERJA DAN KEPUASAN KERJA TERHADAP KINERJA KARYAWAN
}

(Studi Divisi Quality Control PT. ABC)

\author{
Suroso \\ suroso@ubpkarwang.ac.id \\ Fakultas Ekonomi dan Bisnis, Universitas Buana Perjuangan Karawang
}

\begin{abstract}
ABSTRAK
Tujuan penelitian ini adalah untuk menganalisis bagaimana pengaruh motivasi kerja dan kepuasan kerja terhadap kinerja karyawan di Divisi Quality Control PT.ABC. Kemampuan sebuah perusahaan dalam memberikan motivasi kerja kepada karyawan menjadi salah satu cara untuk meningkatkan kinerja karyawan dan berdampak pada hasil yang dicapai. Kinerja karyawan yang baik tentunya akan berpengaruh pada hasil kerja yang baik juga. Kepuasan kerja yang didapat karyawan menjadi salah satu penentu bagi terlaksananya dengan baik setiap target kerja yang diinginkan oleh perusahaan. Oleh sebab itu, motivasi kerja dan kepuasan kerja memiliki peran penting dalam kinerja karyawan dalam upayanya untuk meningkatkan kinerja karyawan di Divisi Quality Control PT.ABC.

Metode penelitian yang digunakan metode analisis kuantitatif. Pengolahan data statistik dalam penelitian ini dengan menggunakan aplikasi SPSS. Teknik pengumpulan data menggunakan wawancara dan angket dengan menggunakan teknik sensus sebanyak 83 orang karyawan pada divisi Quality Control.

Hasil analisis dan pembahasan didapat hasil analisis deskriptrif yaitu Motivasi kerja karyawan pada divisi quality control PT. ABC sudah tinggi dengan skor nilai 301,6. Kepuasan kerja karyawan pada divisi quality control PT. ABC sudah tinggi dengan skor nilai 316,1. Kinerja karyawan pada divisi quality control PT. ABC sudah tinggi dengan skor nilai 320,7. Sedangkan analisis verifikatif yaitu terdapat pengaruh Motivasi kerja secara signifikan terhadap Kinerja karyawan pada divisi quality control PT. ABC dengan besaran pengaruh sebesar $17,1 \%$. Terdapat pengaruh Kepuasan kerja secara signifikan terhadap Kinerja karyawan pada divisi quality control PT. ABC dengan besaran pengaruh sebesar 23,3\%. Terdapat pengaruh signifikan Motivasi kerja dan Kepuasan kerja secara simultan terhadap kinerja karyawan pada divisi quality control PT.ABC dengan besaran pengaruh sebesar $28 \%$.
\end{abstract}

KATA KUNCI: Motivasi kerja, kepuasan kerja, kinerja karyawan.

\section{PENDAHULUAN}

PT. ABC merupakan salah satu perusahaan yang bergerak dibidang manufacturing, sebagai salah satu perusahaan yang tujuan utamanya adalah memberikan kepuasan kepada konsumen, karyawan pada PT.ABC menjadi salah satu kunci utama perusahaan dalam memberikan pelayanan kepada konsumen. 
Kinerja karyawan yang tinggi menjadi salah satu capaian bagi perusahaan untuk meraih pasar yang luas. Berikut adalah data sekunder yang didapat dari PT.ABC.

Tingkat turnover karyawan yang ada di PT.ABC setiap tahunnya mengalami naik turun. Dari tahun 2015 jumlah turnover karyawan divisi Quality Control sebanyak 5,1\% dan di tahun 2016 menurun sebanyak 3,8\%, namun di tahun 2017 terjadi peningkatan turnover sebanyak 4,8\%, berdasarkan informasi yang didapat dari hasil evaluasi perusahaan karyawan yang keluar dikarenakan tidak sesuai target yang diharapkan, terlalu banyaknya barang NG (not good) yang lolos pada proses produksi selanjutnya. Karena tugas pokok karyawan quality control yang paling penting memastikan proses barang baik. Hal ini membuktikan bahwa peran perusahaan dalam memberikan motivasi kerja dan kepuasan kerja sangatlah berpengaruh pada hasil kerja yang didapat karyawan yang berujung pada kinerja karyawan tersebut.

Perkembangan kinerja karyawan PT. ABC mengalami tren perbaiakan di akhir tahun. Akan tetapi pada awal tahun 2018 sangat banyak claim dari customer. Pada bulan Januari 2018 frekwensi claim menunjukan 19 kasus, namun pada bulan berikutnya mengalami perbaikan sebesar 11 kasus. Pada bulan Maret 2018 mengalami kenaikan menjadi 16 kasus. Kesalahan claim customer tersebut kebanyakan oleh kinerja karyawan quality control yang kurang optimal. Ketidaktelitian dan kesalahan atas lolosnya barang NG (not good) menunjukan indikator kurang optimalnya kinerja karyawan bagian quality control. Dengan demikian perlu adanya perbaikan yang mendalam atas kinerja karyawan.

PT.ABC selalu berupaya untuk melakukan peningkatan kualitas kinerja karyawannya dengan berbagai cara yaitu memberikan insentif pada hasil kerja, jenjang karir bagi setiap karyawan, mengikutsertakan karyawan dalam kegiatan pelatihan-pelatihan yang bertujuan untuk menggali kompetensi kerja karyawan, dan motivasi lainnya seperti liburan (Gathering). Namun demikian hal tersebut nyatanya belum bisa memberikan kepuasan kepada karyawan sehingga hasil kerja yang diharapkan tidak sesuai dengan yang diinginkan perusahaan, seperti banyaknya keluhan konsumen atas hasil produksi terhadap order produk sebelumnya, proses pendistribusian produk, kesulitan dalam berkomunikasi 
dengan baik kepada konsumen yang tentunya sangat berpengaruh pada target produksi perusahaan.

Permasalahan yang terdapat pada pendahuluan tersebut dapat diajukan rumusan masalah sehingga dapat menjawab permasalahan penelitian yaitu “ Bagaimana pengaruh motivasi kerja dan kepuasan kerja terhadap kinerja karyawan divisi quality PT. ABC dengan menggunakan dimensi kebutuhan berprestasi, kebutuhan berinteraksi, kebutuhan kekuasaan, pekerjaan itu sendiri, gaji, promosi, supervisi dan kelompok kerja"

Penelitian ini bertujuan untuk menguraikan permasalahan penelitian dengan menggunakan pengaruh motivasi kerja dan kepuasan kerja terhadap kinerja karyawan divisi quality PT. ABC dengan menggunakan dimensi kebutuhan berprestasi, kebutuhan berinteraksi, kebutuhan kekuasaan, pekerjaan itu sendiri, gaji, promosi, supervisi dan kelompok kerja.

\section{KAJIAN TEORI}

\section{MOTIVASI KERJA}

Fadhil dan Mayowan (2018) menyatakan bahwa motivasi kerja merupakan suatu kekuatan potensial yang berada dalam diri seseorang yang dapat dipengaruhi oleh kekuatan luar berupa imbalan moneter dan imbalan non moneter sehingga berdampak pada hasil kinerja baik berupa secara positif atau secara negatif, hal tersebut tergantung pada situasi atau kondisi oleh yang bersangkutan.

Motivasi merupakan salah satu faktor penting bagi seseorang maupun kelompok dalam upaya memenuhi kebutuhannya untuk meningkatkan kinerja yang berasal dari luar/ eksternal dan sangat berdampak pada hasil kerja yang dilakukan.

\section{KEPUASAN KERJA}

Menurut Rivai dan Sagala (2011) kepuasan kerja merupakan penilaian untuk mencerminkan karyawan atas perasaan senang atau tidak senang; puas atau tidak puas dalam menjalankan suatu pekerjaan. Sedangkan pendapat ahli yang lainya Mangkunegara (2011) kepuasan kerja merupakan perasaan yang pada diri pegawai yang berhubungan dengan pekerjaannya maupun dengan kondisi dirinya. Perasaan tersebut berhubungan dengan pekerjaan meliputi seperti kesempatan pengembangan karir, gaji yang diterima, interaksi dengan pegawai lainnya, jenis 
pekerjaan, penempatan kerja, struktur organisasi perusahaan dan lain-lain. sedangkan berhubungan dengan dirinya antara lain kondisi kesehatan, kemampuan, umur, dan pendidikan.

Maka perusahaan perlu menilai faktor-faktor yang akan mempengaruhi kinerja karyawan. Didalam melakukan pekerjaan terdapat kriteria yang harus

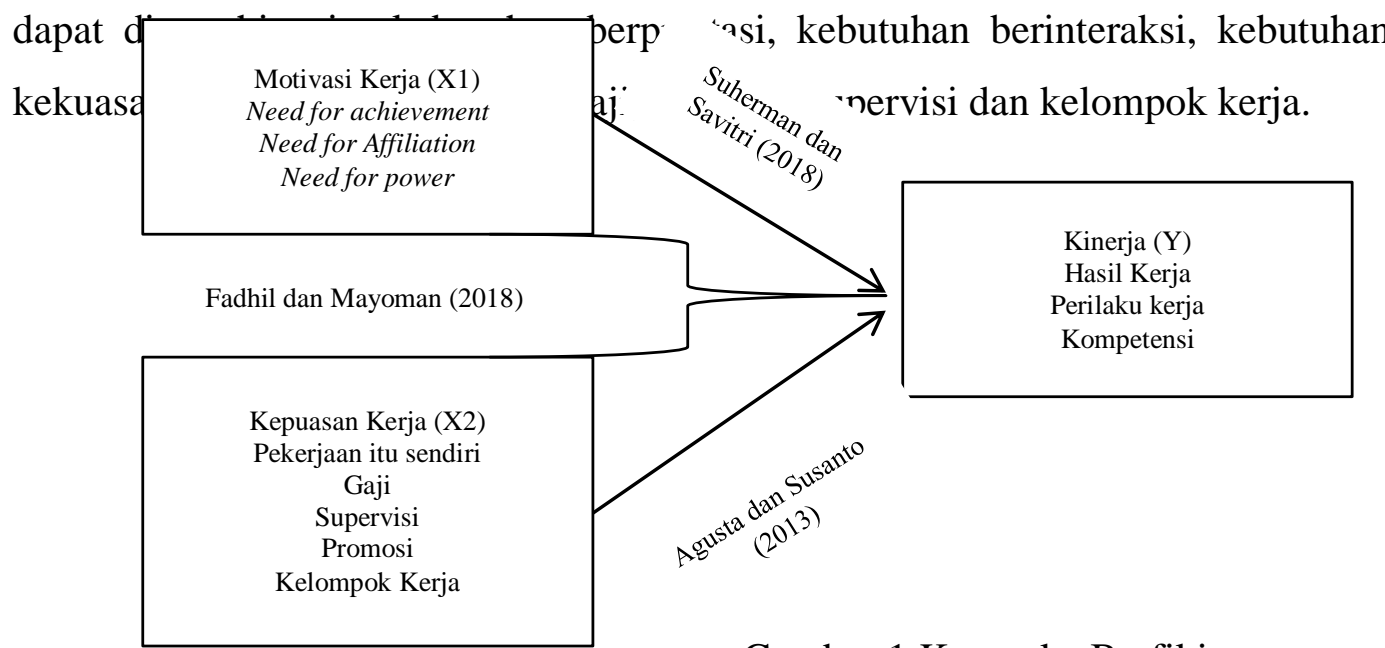

Gambar 1 Kerangka Berfikir

\section{METODE PENELITIAN}

Penelitian ini menggunakan metodologi pendekatan deskriptif verifikatif, yaitu untuk menganalisis pengaruh motivasi kerja dan kepuasan kerja karyawan terhadap kinerja karyawan.

Variabel dalam penelitian ini meliputi motivasi kerja dan kepuasan kerja. yang dijelaskan dengan indikator-indikator pada operasional sebagai berikut :

\section{Tabel 1}

\section{Operasionalisasi Variabel}

\begin{tabular}{|c|c|c|}
\hline Variabel & Dimensi & Indikator \\
\hline $\begin{array}{l}\text { Motivasi } \\
\text { Kerja }\end{array}$ & $\begin{array}{l}\text { Need for Affiliation } \\
\text { Need for power }\end{array}$ & $\begin{array}{l}\text { a. Keberhasilan Pelaksanaan } \\
\text { b. Pengakuan prestasi } \\
\text { c. Inovatif } \\
\text { d. Tanggung jawab } \\
\text { a. Persahabatan } \\
\text { b. Bekerjasama } \\
\text { c. Konflik } \\
\text { a. Kepercayaan menjadi pemimpin } \\
\text { b. Tugas dibebankan } \\
\text { c. Kontribusi }\end{array}$ \\
\hline $\begin{array}{l}\text { Kepuasan } \\
\text { kerja }\end{array}$ & $\begin{array}{l}\text { 1. Pekerjaan itu } \\
\text { sendiri } \\
\text { 2. Gaji } \\
\text { 3. Promosi }\end{array}$ & $\begin{array}{ll}\text { a. } & \text { Karakteristik pekerjaan } \\
\text { b. } & \text { Beban pekerjaan } \\
\text { a. } & \text { Kontribusi kerja dengan kompensasi } \\
\text { a. } & \text { Pengembangan diri } \\
\text { b. } & \text { Pengembangan karier }\end{array}$ \\
\hline
\end{tabular}




\begin{tabular}{|c|c|c|}
\hline & $\begin{array}{l}\text { 4. Supervisi } \\
\text { 5. Kelompok kerja }\end{array}$ & $\begin{array}{ll}\text { a. Gaya pengawasan } \\
\text { a. Hubungan kerja } \\
\text { b. Rekan Kooperatif }\end{array}$ \\
\hline $\begin{array}{l}\text { Kinerja } \\
\text { Karyawan }\end{array}$ & $\begin{array}{l}\text { 1. Hasil kerja } \\
\text { 2. Perilaku } \\
\text { 3. Kompetensi }\end{array}$ & $\begin{array}{l}\text { a. Menjalankan pekerjaan dengan standar } \\
\text { b. Pencapaian target tepat waktu dan konsisten } \\
\text { c. Penjualan mencapai target } \\
\text { a. Berperilaku sopan santun dalam pelayanan } \\
\text { b. Kerjasama } \\
\text { c. Tanggung jawab } \\
\text { a. Pemberian komunikasi menyenangkan } \\
\text { b. Komunikasi memberikan pemahaman } \\
\text { c. Keterampilan }\end{array}$ \\
\hline
\end{tabular}

Sumber: Olah data 2019

Populasi penelitian ini adalah seluruh karyawan PT.ABC berjumlah 83 Orang. Sampel yang digunakan adalah sampel sensus berjumlah 83 orang. Sedangkan teknik pengumpulan data menggunakan teknik angket dan wawancara terbatas untuk memperoleh informasi tertentu. Alternative yang digunakan adalah skala likert. Skala likert digunakan untuk mengukur sikap, pendapat responden tentang fenomena social. Adapun skala yang digunakan (sangat baik, baik, cukup baik, kurang baik, tidak baik).

Analisis data penelitian menggunakan metode deskriptif kualitatif dengan menggunakan analisis regresi berganda dengan rangkaian penghitungan sebagai berikut:

1. Transformasi data. Teknik transformasi yang paling sederhana dengan menggunakan MSI (Method of Successive Interval). Untuk mempermudah dalam pengolahan data penulis, maka penulis menggunakan software MSI STAT97

2. Uji keabsahan data, Uji keabsahan data menggunakan uji validitas dan reliabilitas yaitu dengan menggunakan analisis corrected item total Correlation dan Croanbach's Alpha (SPSS)

a. Validitas $r$ hitung $>0,3$ ( instrument Valid)

b. Reliabilitas Croanch's Alpha >0,6 (instrument Reliabel )

c. Uji Normalitas. Uji prasyarat menggunakan uji normalitas menggunakan Kolmogorov-smirnov dengan menggunakan SPSS. Uji Normalitas Sig. Hitung >0,05 berdistribusi normal.

d. Penelitian ini untuk menganalisis data hasil angket dengan menggunakan instrumen dari skala likert. Formulasi analisis rentang skala: 


$$
R S=\frac{n \cdot(m-1)}{M}
$$

Dimana:

$\mathrm{n}=$ Jumlah Sampel

$\mathrm{m}=$ Jumlah Alternatif Jawaban $($ skor $=5)$

Rentang Skala (RS) sebesar:

Skala Terendah $=$ Skor Terendah x Jumlah Sampel

Skala Tertinggi $=$ Skor Tertinggi $\mathrm{x}$ Jumlah Sampel

Jumlah sampel sebanyak 83 orang.

Instrumen menggunakan skala likert pada skala terendah 1 dan skala tertinggi 5.

Skala Terendah $=$ Skor Terendah $\times$ Jumlah Sampel $(n)=1 \times 83=833$

Skala Tertinggi $=$ Skor Tertinggi $\times$ Jumlah Sampel $(n)=5 \times 83=415$

Sehingga dalam penelitian ini rentang skalanya adalah:

$R S=\frac{83(5-1)}{5}=66.4$

Tabel 2

Analisis Rentang Skala

\begin{tabular}{|c|c|c|c|c|}
\hline \multirow{2}{*}{ Skala Skor } & \multirow{2}{*}{ Rentang Skala } & Motivasi Kerja & $\begin{array}{c}\text { Kepuasan Kerja } \\
\text { Kerja }\end{array}$ & Kinerja Karayawan \\
\cline { 3 - 5 } & $83-149,4$ & Sangat Rendah & Sangat Tidak Puas & Sangat Tidak Baik \\
\hline 1 & $149,5-215,8$ & Rendah & Tidak Puas & Tidak Baik \\
\hline 2 & $215,9-282,2$ & Cukup Tinggi & Cukup Puas & Kurang Baik \\
\hline 3 & $282,3-348,6$ & Tinggi & Puas & Baik \\
\hline 5 & $348,7-415$ & Sangat Tinggi & Sangat Puas & Sangat Baik \\
\hline
\end{tabular}

Sumber: Hasil Analisis 2019

Analisis Regresi Linier Berganda

Teknik analisis linier berganda digunakan dalam menguji seberapa besar kontribusi variabel independen dalam memperngaruhi varibel dependen. Analisis ini untuk mengetahui arah pengaruh variabel independen terhadap variabel dependen. Pengaruh tersebut dapat berupa positif atau negatif dan Dapat memprediksi nilai dari variabel dependen jika nilai variabel independen mengalami kenaikan atau penurunan 
Adapun persamaan regresi liner berganda yaitu sebagai berikut:

$$
\begin{array}{ll}
\mathrm{Y}=\mathrm{a}+\mathrm{b} 1 \mathrm{X} 1+\mathrm{b} 2 \mathrm{X} 2 \\
\mathrm{Y} & =\text { Variabel Dependen } \\
\mathrm{X} 1, \mathrm{X} 2 & =\text { Variabel Independen } \\
\mathrm{a} & =\text { Konstanta } \\
\mathrm{b} & =\text { Koefisien regresi (nilai peningkatan atau penurunan) }
\end{array}
$$

Analisis selanjutnya adalah analisis Determinasi dalam regresi linear berganda digunakan untuk mengetahui prosentase pengaruh variabel independen $\left(\mathrm{X}_{1}, \mathrm{X}_{2}, \ldots \ldots \mathrm{X}_{\mathrm{n}}\right)$ secara serentak terhadap variabel dependen $(\mathrm{Y})$. Koefisien ini menunjukkan seberapa besar prosentase variasi variabel independen yang digunakan dalam model mampu menjelaskan variasi variabel dependen. $\mathrm{R}^{2}$ sama dengan 0 , maka tidak ada sedikitpun prosentase sumbangan pengaruh yang diberikan variabel independen terhadap variabel dependen, atau variasi variabel independen yang digunakan dalam model tidak menjelaskan sedikitpun variasi variabel dependen. Sebaliknya $\mathrm{R}^{2}$ sama dengan 1 , maka prosentase sumbangan pengaruh yang diberikan variabel independen terhadap variabel dependen adalah sempurna, atau variasi variabel independen yang digunakan dalam model menjelaskan $100 \%$ variasi variabel dependen.

\section{HASIL DAN PEMBAHASAN}

\section{HASIL :}

\section{HASIL ANALISIS DESKRIPTIF}

Berdasarkan pengumpulan data yang dilakukan melalui angket penelitian didapatkan data angket sebagai berikut :

a. Deskriptif Motivasi Kerja

Tabel 3 Deskriptif Motivasi Kerja

\begin{tabular}{|c|c|c|c|c|c|c|c|c|c|c|c|}
\hline \multirow{2}{*}{ Pernyataan } & \multicolumn{5}{|c|}{ Skala } & \multicolumn{5}{c|}{ Skor Skala } & \multirow{2}{*}{ Total Skor } \\
\cline { 2 - 13 } & 5 & 4 & 3 & 2 & 1 & 5 & 4 & 3 & 2 & 1 & \\
\hline X1-1 & 32 & 21 & 26 & 4 & 0 & 160 & 84 & 78 & 8 & 0 & 330 \\
\hline X1-2 & 17 & 25 & 39 & 1 & 1 & 85 & 100 & 117 & 2 & 1 & 305 \\
\hline X1-3 & 14 & 24 & 41 & 3 & 1 & 70 & 96 & 123 & 6 & 1 & 296 \\
\hline X1-4 & 18 & 27 & 37 & 1 & 0 & 90 & 108 & 111 & 2 & 0 & 311 \\
\hline X1-5 & 16 & 27 & 37 & 3 & 0 & 80 & 108 & 111 & 6 & 0 & 305 \\
\hline$X 1-6$ & 19 & 25 & 34 & 5 & 0 & 95 & 100 & 102 & 10 & 0 & 307 \\
\hline$X 1-7$ & 17 & 19 & 41 & 6 & 0 & 85 & 76 & 123 & 12 & 0 & 296 \\
\hline
\end{tabular}


Suroso

Vol 5 No 1

ISSN: $2528-0597$

E-ISSN: 2580-5428

\begin{tabular}{|c|c|c|c|c|c|c|c|c|c|c|c|}
$\mathrm{X} 1-8$ & 13 & 20 & 43 & 6 & 1 & 65 & 80 & 129 & 12 & 1 & 287 \\
\hline $\mathrm{X} 1-9$ & 14 & 14 & 50 & 4 & 1 & 70 & 56 & 150 & 8 & 1 & 285 \\
\hline $\mathrm{X} 1-10$ & 14 & 22 & 42 & 5 & 0 & 70 & 88 & 126 & 10 & 0 & 294 \\
\hline Range Skor & 415 & 332 & 249 & 166 & 83 & \multicolumn{6}{|c|}{301,6} \\
\hline
\end{tabular}

Sumber data olah 2019

Berdasarkan hasil analisis deskriptif motivasi kerja memiliki total skor 301,6 memiliki range skor skala 3 dan skor 4 atau motivasi tinggi.

b. Deskriptif Kepuasan Kerja

Tabel 4 Deskriptif Kepuasan Kerja

\begin{tabular}{|c|c|c|c|c|c|c|c|c|c|c|c|}
\hline \multirow{2}{*}{ Pernyataan } & \multicolumn{5}{|c|}{ Skala } & \multicolumn{5}{|c|}{ Skor Skala } & \multirow{2}{*}{$\begin{array}{l}\text { Total } \\
\text { Skor }\end{array}$} \\
\hline & 5 & 4 & 3 & 2 & 1 & 5 & 4 & 3 & 2 & 1 & \\
\hline X2-1 & 21 & 25 & 32 & 4 & 1 & 105 & 100 & 96 & 8 & 1 & 310 \\
\hline X2-2 & 28 & 29 & 24 & 2 & 0 & 140 & 116 & 72 & 4 & 0 & 332 \\
\hline X2-3 & 25 & 29 & 25 & 2 & 2 & 125 & 116 & 75 & 4 & 2 & 322 \\
\hline X2-4 & 23 & 26 & 31 & 2 & 1 & 115 & 104 & 93 & 4 & 1 & 317 \\
\hline $\mathrm{X} 2-5$ & 13 & 34 & 27 & 6 & 3 & 65 & 136 & 81 & 12 & 3 & 297 \\
\hline$X 2-6$ & 18 & 32 & 29 & 4 & 0 & 90 & 128 & 87 & 8 & 0 & 313 \\
\hline X2-7 & 25 & 27 & 28 & 0 & 3 & 125 & 108 & 84 & 0 & 3 & 320 \\
\hline $\mathrm{X} 2-8$ & 29 & 23 & 21 & 8 & 2 & 145 & 92 & 63 & 16 & 2 & 318 \\
\hline Range Skor & 415 & 332 & 249 & 166 & 83 & & & & 611 & & \\
\hline
\end{tabular}

Sumber data olah 2019

Berdasarkan hasil analisis deskriptif kepuasan kerja memiliki total skor 316,2 memiliki range skor skala 3 dan skor 4 atau kepuasan kerja puas.

c. Deskriptif Kinerja Karyawan

Tabel 5 Deskriptif Kinerja Karyawan

\begin{tabular}{|c|c|c|c|c|c|c|c|c|c|c|c|}
\hline \multirow{2}{*}{ Pernyataan } & \multicolumn{5}{|c|}{ Skala } & \multicolumn{5}{|c|}{ Skor Skala } & \multirow{2}{*}{$\begin{array}{l}\text { Total } \\
\text { Skor }\end{array}$} \\
\hline & 5 & 4 & 3 & 2 & 1 & 5 & 4 & 3 & 2 & 1 & \\
\hline $\mathrm{Y} 1$ & 29 & 26 & 27 & 1 & 0 & 145 & 104 & 81 & 2 & 0 & 332 \\
\hline $\mathrm{Y} 2$ & 25 & 30 & 25 & 3 & 0 & 125 & 120 & 75 & 6 & 0 & 326 \\
\hline Y3 & 19 & 34 & 28 & 1 & 1 & 95 & 136 & 84 & 2 & 1 & 318 \\
\hline $\mathrm{Y} 4$ & 28 & 26 & 29 & 0 & 0 & 140 & 104 & 87 & 0 & 0 & 331 \\
\hline Y5 & 20 & 33 & 28 & 1 & 1 & 100 & 132 & 84 & 2 & 1 & 319 \\
\hline Y6 & 19 & 30 & 32 & 0 & 2 & 95 & 120 & 96 & 0 & 2 & 313 \\
\hline $\mathrm{Y7}$ & 18 & 31 & 26 & 7 & 1 & 90 & 124 & 78 & 14 & 1 & 307 \\
\hline Y8 & 24 & 26 & 32 & 0 & 1 & 120 & 104 & 96 & 0 & 1 & 321 \\
\hline $\mathrm{Y9}$ & 24 & 25 & 32 & 1 & 1 & 120 & 100 & 96 & 2 & 1 & 319 \\
\hline Range Skor & 415 & 332 & 249 & 166 & 83 & & & & & & \\
\hline
\end{tabular}

Sumber data olah 2019

Berdasarkan hasil analisis deskriptif kinerja karyawan memiliki total skor 320,7 memiliki range skor skala 3 dan skor 4 atau kinerja karyawan baik.

2. HASIL ANALISIS VERIFIKATIF 
Analisis verifikatif menggunakan analisis regresi linier berganda. Sebelum menganalisis data perlu memerlukan analisis prasyarat yaitu sebagai berikut:

a. Analisis Prasyarat

Analisis prasyarat digunakan untuk mengolah data kuesionar yang berasal dari data ordinal ditransformasikan menjadi data interval, menganalisis uji validitas dan reliabitas sebagai uji kontruks alat penelitian. Berikut beberapa analisis yang diperlukan untuk analisis prasyarat sebagai berikut:

1) Analisis Uji Validitas

Disajikan data uji validitas menggunakan analisis product moment pearson yaitu:

Tabel 6 Uji Validitas

\begin{tabular}{|c|c|c|c|c|c|c|c|c|c|c|}
\hline \multicolumn{11}{|c|}{ Variabel Motivasi Kerja } \\
\hline Indikator & X1-1 & $\mathbf{X 1 - 2}$ & $\mathbf{X 1 - 3}$ & X1-4 & X1-5 & X1-6 & $\mathbf{X 1 - 7}$ & $\mathbf{X 1 - 8}$ & X1-9 & X1-10 \\
\hline Rxy & 0,64 & 0,64 & 0,50 & 0,60 & 0,45 & 0,60 & 0,76 & 0,68 & 0,73 & 0,80 \\
\hline Status & Valid & Valid & Valid & Valid & Valid & Valid & Valid & Valid & Valid & Valid \\
\hline \multicolumn{11}{|c|}{ Variabel Kepuasan Kerja } \\
\hline Indikator & $\mathrm{X} 2-1$ & $\mathrm{X} 2-2$ & $\mathrm{X} 2-3$ & $X 2-4$ & $\mathrm{X} 2-5$ & $\mathrm{X} 2-6$ & $\mathrm{X} 2-7$ & $\mathrm{X} 2-8$ & & \\
\hline Rxy & 0,71 & 0,80 & 0,84 & 0,83 & 0,59 & 0,76 & 0,77 & 0,83 & & \\
\hline Status & Valid & Valid & Valid & Valid & Valid & Valid & Valid & Valid & & \\
\hline
\end{tabular}

Sumber data olah 2019

Tabel 6 Uji Validitas (Lanjutan)

\begin{tabular}{|c|c|c|c|c|c|c|c|c|c|}
\hline \multicolumn{10}{|c|}{ Variabel Kinerja Karyawan } \\
\hline Indikator & $\mathrm{Y} 1$ & $\mathrm{Y} 2$ & Y3 & Y4 & Y5 & Y6 & $\mathrm{Y7}$ & Y8 & Y9 \\
\hline Rxy & 0,69 & 0,73 & 0,85 & 0,68 & 0,83 & 0,86 & 0,81 & 0,77 & 0,86 \\
\hline Status & Valid & Valid & Valid & Valid & Valid & Valid & Valid & Valid & Valid \\
\hline
\end{tabular}

Sumber data olah 2019

Berdasarkan tabel 6 uji validitas setiap variabel dapat dinyatakan valid. Hal ini dapat dibuktikan rxy hitung setiap indikator pada masing-masing variabel $>r$ kritis. $r$ kritis yang digunakan adalah 0,3.

2) Analisis Uji Reliabilitas

Reliability Statistics

\begin{tabular}{|r|r|}
\hline $\begin{array}{c}\text { Cronbach's } \\
\text { Alpha }\end{array}$ & N of Items \\
\hline .841 & 10 \\
\hline
\end{tabular}

Motivasi Kerja
Reliability Statistics

\begin{tabular}{|r|r|}
\hline $\begin{array}{c}\text { Cronbach's } \\
\text { Alpha }\end{array}$ & Nof Items \\
\hline .900 & 8 \\
\hline
\end{tabular}

Kepuasan Kerja

Reliability Statistics

\begin{tabular}{|r|r|}
\hline $\begin{array}{c}\text { Cronbach's } \\
\text { Alpha }\end{array}$ & N of Items \\
\hline .922 & 9 \\
\hline
\end{tabular}

Kineria Karyawan 
Berdasarkan uji reliabilitas pada gambar 2 menunjukan bahwa untuk setiap variabel nilai conbach's alpha lebih besar 0,6. Artinya item pertanyaan untuk semua variabel dapat dinyatakan sebagai reliabel. Variabel motivasi kerja nilai conbach's alpha bernilai 0,841, variabel kepuasan kerja nilai conbach's alpha bernilai 0,9 , dan variabel kinerja kinerja karyawan nilai conbach's alpha bernilai 0,922 .

\section{3) Analisis Uji Normalitas}

Hasil uji normalitas pada gambar 3 menunjukan bahwa nilai sig (2-talled) lebih besar dari sig (2-talled) kritis adalah 0,05. Untuk variabel motivasi kerja nilai sig 0,385 > 0,05 dinyatakan berdistribusi normal. Untuk variabel kepuasan kerja nilai sig 0,345>0,05 dinyatakan berdistribusi normal. Sedangkan variabel kinerja karyawan nilai sig 0,106 >0,05 dinyatakan berdistribusi normal.

Hasil uji normalitas dapat disajikan pada gambar 3 hasil analisis data menggunakan SPSS 20 yaitu sebagai berikut:

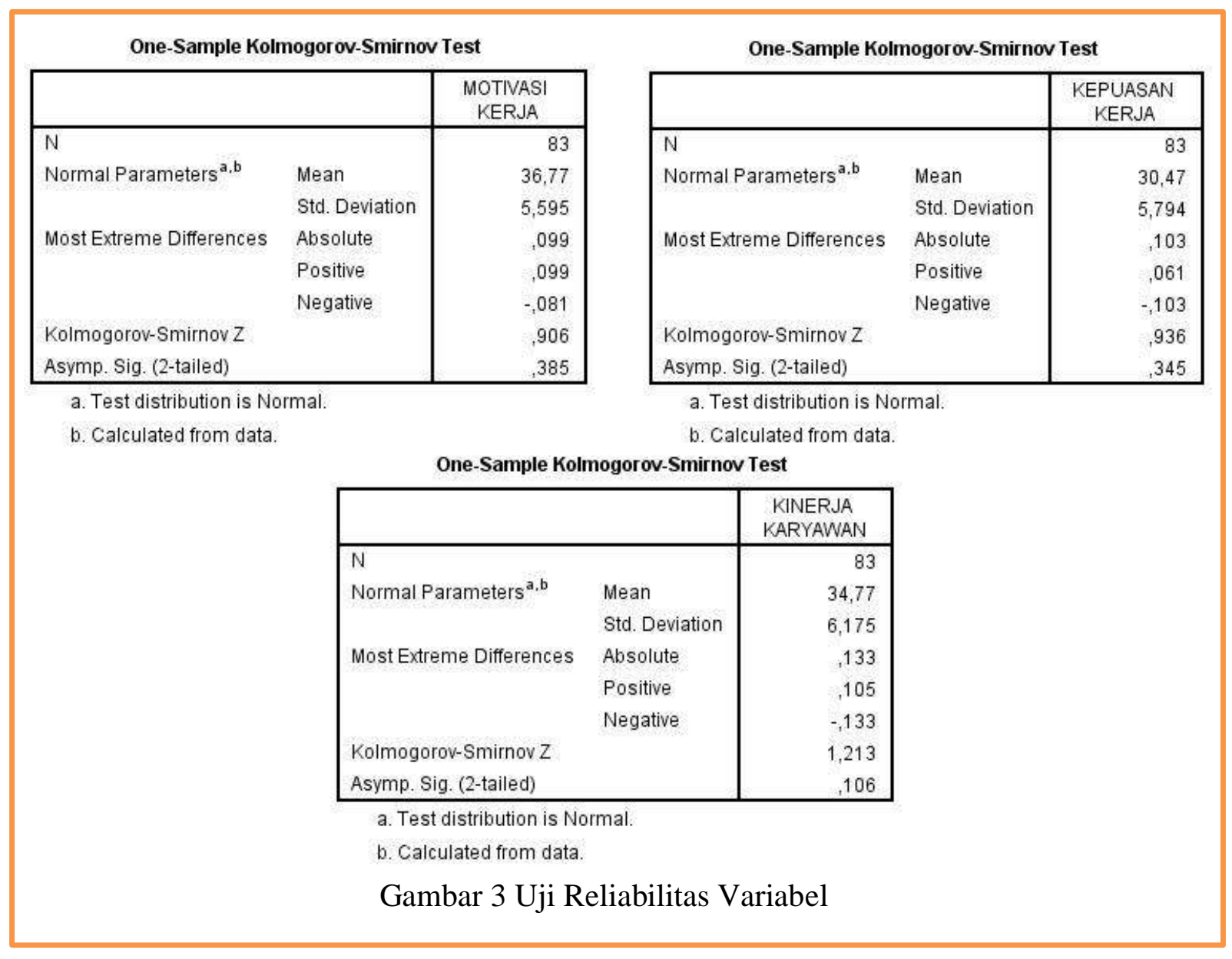


4) Transformasi Data

Adapun transformasi data menggunakan analisis MSI dengan menggunakan software excel.

Analisis Regresi Linier Berganda.

Upaya menganalisis verifikatif penelitian ini diperlukan metode analisis regresi liner berganda dengan persamaan dan perhitungan spss sebagai berikut:

$\mathrm{Y}=\mathrm{a}+\mathrm{b} 1 \mathrm{x} 1+\mathrm{b} 2 \mathrm{x} 2$

Berdasarkan gambar 4 dilihat bahwa konstanta linier berganda bernilai 12,536. Koefisien $\mathrm{b}$ motivasi kerja bernilai 0,152. Sedangkan koefisien b kepuasan kerja bernilai 0,481. Maka dapat persamaan linier berganda sebagai berikut:

$\mathrm{Y}=10,159+0,242 \mathrm{X} 1+0,372 \mathrm{X} 2$

Penyajian data berdasarkan hasil analisis SPSS 20 menggunakan analisis regresi berganda dapat dilihat sebagai berikut:

\begin{tabular}{|ll|r|r|r|}
\hline \multicolumn{1}{|c|}{ Correlations } \\
& & $\begin{array}{c}\text { Kinerja } \\
\text { Karyawan }\end{array}$ & $\begin{array}{c}\text { Kepuasan } \\
\text { Kerja }\end{array}$ \\
\hline Pearson Correlation & Kinerja Karyawan & 1,000 &, 414 &, 483 \\
& Motivasi Kerja &, 414 & 1,000 &, 462 \\
& Kepuasan Kerja &, 483 &, 462 & 1,000 \\
\hline Sig. (1-tailed) & Kinerja Karyawan & &, 000 &, 000 \\
& Motivasi Kerja &, 000 &, 000 \\
& Kepuasan Kerja &, 000 &, 000 & 83 \\
& Kinerja Karyawan & 83 & 83 & 83 \\
& Motivasi Kerja & 83 & 83 & 83 \\
\hline
\end{tabular}

\section{Model Summary}

\begin{tabular}{|l|l|r|r|r|}
\hline Model & R & R Square & $\begin{array}{c}\text { Adjusted R } \\
\text { Square }\end{array}$ & $\begin{array}{c}\text { Std. Error of } \\
\text { the Estimate }\end{array}$ \\
\hline 1 & $529^{\mathrm{a}}$ &, 280 &, 262 & 5,563 \\
\hline
\end{tabular}

a. Predictors: (Constant), Kepuasan Kerja, Motivasi Kerja

Coefficients $^{a}$

\begin{tabular}{|c|c|c|c|c|c|c|}
\hline \multirow{2}{*}{\multicolumn{2}{|c|}{ Model }} & \multicolumn{2}{|c|}{ Unstandardized Coefficients } & \multirow{2}{*}{$\begin{array}{c}\text { Standardized } \\
\text { Coefficients } \\
\text { Beta } \\
\end{array}$} & \multirow[b]{2}{*}{$\mathrm{t}$} & \multirow[b]{2}{*}{ Sig. } \\
\hline & & $\mathrm{B}$ & Std. Error & & & \\
\hline \multirow[t]{3}{*}{1} & (Constant) & 10,159 & 3,789 & & 2,681 &, 009 \\
\hline & Motivasi Kerja &, 265 &, 117 &, 242 & 2,260 &, 027 \\
\hline & Kepuasan Kerja & 422 & 121 & 372 & 3,474 &, 001 \\
\hline
\end{tabular}
kna setiap 1 poin kerja maka akan

a. Dependent Variable: Kinerja Karyawan

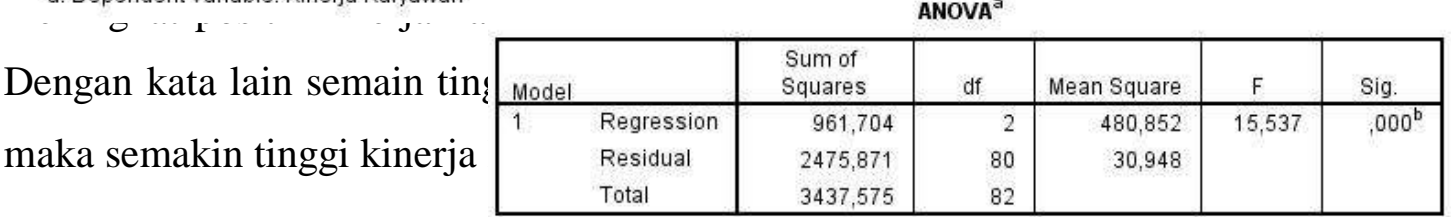


1) Analisis pengaruh motivasi kerja terhadap kinerja karyawan.

Pengaruh motivasi kerja terhadap kinerja karyawan dapat dilihat berdasarkan uji t. t hitung motivasi kerja pada gambar coefficients sebesar 3,347 lebih besar dari t tabel sebesar 1,98. Sedangkan koefisien korelasi motivasi kerja dengan kinerja karyawan sebesar 0,414 atau $\mathrm{r}$ square sebesar 0,171 atau pengaruhnya sekitar $17,1 \%$. Dengan demikian Ho ditolak yakni terdapat pengaruh signifikan motivasi kerja terhadap kinerja karyawan dengan bersaran pengaruh sebesar $17,1 \%$.

2) Analisis pengaruh kepuasan kerja terhadap kinerja karyawan

Pengaruh kepuasan kerja terhadap kinerja karyawan dapat dilihat berdasarkan uji t. t hitung kepuasan kerja pada gambar coefficients sebesar 2,26 lebih besar dari t tabel sebesar 1,98. Sedangkan koefisien korelasi kepuasan kerja dengan kinerja karyawan sebesar 0,483 atau $r$ square sebesar 0,233 atau pengaruhnya sekitar 23,3\%. Dengan demikian Ho ditolak yakni terdapat pengaruh signifikan kepuasan kerja terhadap kinerja karyawan dengan bersaran pengaruh sebesar $23,3 \%$.

3) Analisis pengaruh motivasi kerja dan kepuasan kerja terhadap kinerja karyawan.

Pengaruh motivasi kerja dan kepuasan kerja terhadap kinerja karyawan dapat dilihat berdasarkan uji f. f hitung kepuasan kerja pada gambar anova sebesar 15,537 lebih besar dari f tabel sebesar 3,11. Sedangkan koefisien korelasi simultan motivasi kerja dan kepuasan kerja dengan kinerja karyawan sebesar 0,529 atau $r$ square sebesar 0,280 atau pengaruhnya sekitar 28\%. Dengan demikian Ho ditolak yakni terdapat pengaruh signifikan motivasi kerja dan kepuasan kerja secara bersama-sama terhadap kinerja karyawan dengan bersaran pengaruh sebesar $28 \%$.

\section{PEMBAHASAN}

\section{PEMBAHASAN ANALISIS DESKRIPTIF}

Analisis deskriptif membahas bagaimana kondisi keadaan masing-masing variabel penelitian. Variabel tersebut meliputi motivasi kerja, kepuasan kerja dan kinerja karyawan. 
Analisis deskriptif untuk variabel motivasi kerja memiliki kriteria tinggi dengan skor 301,6. Nilai skor tertinggi pada indikator keberhasilan pelaksanaan pada nilai skor 330 sedangkan nilai skor terendah pada indikator kepercayaan menjadi pemimpin pada nilai skor 287.

Analisis deskriptif untuk variabel kepuasan kerja memiliki kriteria puas dengan skor 316,1. Nilai skor tertinggi pada indikator beban pekerjaan pada nilai skor 332 sedangkan nilai skor terendah pada indikator pengembangan karier pada nilai skor 297.

Analisis deskriptif untuk variabel kinerja karyawan memiliki kriteria tinggi dengan skor 320. Nilai skor tertinggi pada indikator menjalankan pekerjaan sesuai standar pada nilai skor 332 sedangkan nilai skor terendah pada indikator komunikasi menyenangkan pada nilai skor 307.

\section{PEMBAHASAN ANALISIS VERIFIKATIF}

a. Pengaruh motivasi kerja terhadap kinerja karyawan.

Pengaruh motivasi kerja terhadap kinerja karyawan dibuktikan dari $\mathrm{t}$ hitung sebesar 3,347 lebih besar dari t tabel sebesar 1,98 dengan $\mathrm{df}=81$. Sedangkan koefisien korelasi motivasi kerja dengan kinerja karyawan sebesar 0,414 dengan tingkat keeratan hubungan sedang atau $\mathrm{r}$ square sebesar 0,171 atau pengaruhnya sekitar 17,1\%. Dengan demikian Ho ditolak yakni terdapat pengaruh signifikan motivasi kerja terhadap kinerja karyawan dengan bersaran pengaruh sebesar $17,1 \%$.

b. Pengaruh kepuasan kerja terhadap kinerja karyawan

Pengaruh kepuasan kerja terhadap kinerja karyawan dibuktikan dengan $\mathrm{t}$ hitung 2,26 lebih besar dari t tabel sebesar 1,98 pada $\mathrm{df}=81$. Sedangkan koefisien korelasi kepuasan kerja dengan kinerja karyawan sebesar 0,483 dengan keeratan hubungan sedang atau $r$ square sebesar 0,233 atau pengaruhnya sekitar 23,3\%. Dengan demikian Ho ditolak yakni terdapat pengaruh signifikan kepuasan kerja terhadap kinerja karyawan dengan bersaran pengaruh sebesar 23,3\% .

c. Pengaruh motivasi kerja dan kepuasan kerja terhadap kinerja karyawan

Pengaruh motivasi kerja dan kepuasan kerja terhadap kinerja karyawan dibuktikan berdasarkan f hitung 15,537 lebih besar dari f tabel sebesar 3,11 pada 
df $1=2$ dan df $2=80$. Sedangkan koefisien korelasi simultan motivasi kerja dan kepuasan kerja dengan kinerja karyawan sebesar 0,529 dengan keeratan hubungan sedang atau $r$ square sebesar 0,280 atau pengaruhnya sekitar 28\%. Dengan demikian Ho ditolak yakni terdapat pengaruh signifikan motivasi kerja dan kepuasan kerja secara bersama-sama terhadap kinerja karyawan dengan bersaran pengaruh sebesar $28 \%$.

\section{KESIMPULAN}

Berdasarkan hasil analisis dan pembahasan dapat ditarik kesimpulan sebagai berikut:

a. Motivasi kerja karyawan pada divisi quality control PT.ABC sudah tinggi dengan skor nilai 301,6. Kepuasan kerja karyawan pada divisi quality control PT.ABC sudah tinggi dengan skor nilai 316,1. Kinerja karyawan pada divisi quality control PT.ABC sudah tinggi dengan skor nilai 320,7.

b. Terdapat pengaruh motivasi kerja secara signifikan terhadap kinerja karyawan pada divisi quality control PT.ABC dengan besaran pengaruh sebesar $17,1 \%$.

c. Terdapat pengaruh kepuasan kerja secara signifikan terhadap kinerja karyawan pada divisi quality control PT.ABC dengan besaran pengaruh sebesar $23,3 \%$.

d. Terdapat pengaruh signifikan motivasi kerja dan kepuasan kerja secara simultan terhadap kinerja karyawan pada divisi quality control PT.ABC dengan besaran pengaruh sebesar $28 \%$.

\section{REFERENSI}

Agusta, Leonando dan Eddy Madiono Sutanto. 2013. Pengaruh Pelatihan da Motivasi Kerja Terhadap Kinerja Karyawan CV. Haragon. Universitas Kristen Petra. Program Studi Manajemen AGORA Vol. 1 No (2013).

Fahmi, Irham. 2013. Manajemen Kinerja Teori dan Aplikasi. Bandung: Alfabeta

Fadhil, Achmad dan Yuniadi Mayowan. 2018. Pengaruh Motivasi Kerja dan Kepuasan Kerja Terhadap Karyawan AJB BUMIPUTERA. Malang: Universitas Brawijaya. Jurnal Administrasi Bisnis. Vol 54 No. 1 
Juniantara, I Wayan. dan I Gede Riana. 2015. Pengaruh Motivasi daj Kepuasan Kerja Terhadap Kinerja Karyawan Koperasi Di Denpasar. Bali: Universitas Udayana. Jurnal Ekonomi dan Bisnis. Vol. 4 No. 9.

Luthans, Fred. 2006. Perilaku organisasi. Edisi 10. Yogyakarta : Andi

Mangkuprawira, Sjafri dan Aida Vitayala Hubies. 2007. Manajemen Mutu Sumber Daya Manusia. Bogor: Ghalia Indonesia

Mangkunegara, Anwar Prabu. 2011. Manajemen Sumber Daya Manusia Perusahaan.Bandung: Remaja Rosda karya

Manullang, M. dan Marihot Amh Manullang.2011. Manajemen Personalia. Yogyakarta: Gajah Mada University Pers

Moeheriono. 2014. Pengukuran Kinerja Berbasis Kompetensi Edisi Revisi. Jakarta: Raja Grafindo Persada

Rivai, Veithzal. Dan Ella Jauvani Sagala. 2011. Edisi Kedua Manajemen Sumber Daya Manusia untuk Perushaan dari Teori ke Praktik. Jakarta: Rajawali Pers

Samsudin, Sadili. 2010. Manajemen Sumber Daya Manusia. Bandung: Pustaka Setia

Sedermayanti. 2014. Manajemen Sumber Daya Manusia Reformasi Birokrasi dan Manajemen Pegawai Negeri Sipil. Bandung: Refika Aditama

Suherman, Enjang dan Citra Savitri. 2018. Analisis Peran Self Efficacy dan Motivasi Kerja Terhadap Kinerja Marketing Dealer Wijaya Toyota Subang. Karawang Jurnal Buana Ilmu. Vol 3 No 1

Sunyoto. Danang. 2012. Manajemen Sumber Daya Manusia. Yogyakarta: CAPS

Suwardi dan Joko Utomo. 2011. Pengaruh Pengaruh Motivasi Kerja, Kepuasan Kerja, Dan Komitmen Organisasional Terhadap Kinerja Pegawai (Studi Pada Pegawai Setda Kabupaten Pati). Kudus: Universitas Muria Kudus. Jurnal Analisis Manajemen. Vol 5. N0 1. 